\title{
DESIGN OF STEEL AND COMPOSITE OPEN CAR PARKS UNDER FIRE
}

\author{
C. Haremza ${ }^{1, *}$, A. Santiago ${ }^{2}$ and L. Simões da Silva ${ }^{3}$ \\ ${ }^{I}$ Ph.D. student, ISISE, Civil Engineering Department, University of Coimbra, Coimbra, Portugal \\ ${ }^{2}$ Assistant Professor, ISISE, Civil Engineering Department, University of Coimbra, Coimbra, Portugal \\ ${ }^{3}$ Full Professor, ISISE, Civil Engineering Department, University of Coimbra, Coimbra, Portugal \\ *(Corresponding author: E-mail: haremza@dec.uc.pt)
}

Received: 2 January 2013; Revised: 21 January 2013; Accepted: 23 January 2013

\begin{abstract}
Steel and concrete are the most commonly used materials for open car park buildings because of their numerous advantages. Open car parks are characterized by high ventilation that keeps the fire limited on the ignition zone, not leading to a flash-over, what justify using fire engineering methodology for assessing the structural behavior of steel and composite open car parks under fire, based on a Natural Fire Concept. The methodology for assessing this structural behavior under fire is presented in this paper, and is characterized by the following steps [1]: i) definition of fire scenario(s), ii) calculation of the rate of heat release and iii) analysis of structural behavior. The research significance of this methodology is justified by the discrepancies on the design requirements for this type of structure in different European countries [2]. At the end of the paper, an example of application of this methodology to fire design an open composite steel-concrete car park with eight floors [3] is presented and is compared to advanced calculation methods.
\end{abstract}

Keywords: Composite steel-concrete structure, Localized fire, Open car park, Rate of heat release, Design methodology

\section{INTRODUCTION}

Steel and concrete are the most commonly used materials for car parking, and open car park buildings with unprotected steel or composite steel-concrete structures is a solution frequently used in many countries of the center and north of Europe, or even in United-States, Canada or Japan. There are many advantages of a composite steel-concrete structure for open car park buildings: i) shorter on-site construction schedule due to the prefabricated elements, and consequently lower construction cost as well as lower environmental impacts during construction; ii) flexible column spacing up to around $16 \mathrm{~m}$, allowing to locate the columns at the back of the parking bay which facilitates vehicles maneuvers [4]; iii) reduced column section size in comparison to a concrete structure, which increases the parking spaces; and iv) reduced weight, and smaller foundations, in comparison to concrete structures [5]. Moreover, steel structures are robust, sustainable, of easy maintenance and easily accommodate vertical enlargement [6].

This solution has become quite competitive since the National regulations have been adapted taking into account the document: Fire safety in open car parks, the oldest reference in this subject, published in 1993, ECCS - European Convention for Constructional Steelwork [7]. This document was a first attempt to clear up the differences between fire safety requirements of open car parks for all European countries, according to information and test results available throughout the world. However, the fire safety requirements, including structural fire ratings and provision of active fire protection system such as sprinklers, still vary between different building codes. In some countries, steel or composite steel-concrete structures are not recommended because steel is required to be fire rated by the building code, and is conditioned by the fire resistance demands $(\mathrm{R})$ from the National regulations. In that case, concrete structure will be more cost effective, despite the numerous advantages of a composite steel-concrete structure. 
A car park as part of a building can be classified as open or closed depending on the ventilation condition. In accordance with ECCS, it may be considered as "open" if, for every parking level, the ventilation areas in the walls are: i) located in at least two opposite façades, ii) equal at least $1 / 3$ of the total surface area of all the walls and iii) correspond to at least $5 \%$ of the floor area of one parking bay [7]. The main advantages of open car parks are: i) lower energy consumption, ii) natural light that contributes to the human comfort and safety of users, iii) natural ventilation, and iv) attractive architectural design. In addition, open car parks present specific characteristics that must be considered in the fire design.

From experimental tests performed in real steel-concrete car parks in 1968, Butcher et al. [8] was the first to conclude that a burning car is unlikely to cause uncontrollable fire spread within a car park and the damage to the car park building is not critical. These results were confirmed by Gewain [9] in 1973, adding that steel provides adequate safety against structural collapse under a car fire. In 1985, Bennetts et al. [10] concluded that the probability to involve more than two cars in a fire is very small because the fire brigades arrive before, and the security could be assured with unprotected steel. More recently, in 2000, three car fire tests were carried out in a two-level braced car park with unprotected steel and concrete slabs, by CTICM - Centre Technique Industriel de la Construction Mécanique, within the European Project - Demonstration of real fire tests in car parks and high buildings ([1];[11]). The aim of these tests was to prove to the French authorities that fire severity achieved by this realistic scenario is lower than the fire severity obtained by the fire curve ISO 834; consequently, reduction or even no fire protection could be accepted. From the two first tests, with three cars and the central one being initially ignited, the authors concluded that the fire engineering methodology based on the scenarios is adequate: the fire spread from one car to another, but structural deformations were far from leading to the collapse of the structure, although some bolt failures were observed. Table 1 presents the peak values of temperatures in steel members according to the previous experimental studies; the older fire tests showed lower temperatures than the recent French test. The evolution of the composition of cars (more plastic, therefore a faster combustion) and the high fuel capacity may explain these higher temperatures.

Table 1. Maximum Steel Temperatures Reached in Fire Tests in Various Countries

\begin{tabular}{|l|c|c|}
\hline \multirow{2}{*}{ Full scale fire tests } & \multicolumn{2}{c|}{ Maximum measured steel temperature } \\
\cline { 2 - 3 } & Beam & Column \\
\hline UK, 1968 [11] & $275^{\circ} \mathrm{C}$ & $360^{\circ} \mathrm{C}$ \\
\hline Japan, 1970 [7] & $245^{\circ} \mathrm{C}$ & $242^{\circ} \mathrm{C}$ \\
\hline USA, 1973 [8] & $226^{\circ} \mathrm{C}$ & - \\
\hline Australia, 1985 [10] & $340^{\circ} \mathrm{C}$ & $320^{\circ} \mathrm{C}$ \\
\hline France, $2000[1]$ & $700^{\circ} \mathrm{C}$ & $640^{\circ} \mathrm{C}$ \\
\hline
\end{tabular}

Additionally to the previous tests, some statistics of real fires in car parks were analyzed in Paris, New Zealand, Brussels, etc... based on the reports from fire brigades. In Paris, three is the maximum number of cars involved in fires and it corresponds to only $10 \%$ of the fires in open car parks buildings. All fires in car parks (with cars or other fire load) were stopped before 1 hour, with $5.5 \%$ of car fires extinguished before the arrival of firemen [1]. In New Zealand, only 3\% of fires involved multiple vehicles [12]. From additional statistics collected in Marseille, Toulouse and Brussels in open car parks [13], it was noticed that a maximum of two cars were involved in a fire, and in Toulouse, only $6.1 \%$ of the fires happened in open car parks. These previous statistics and experimental tests show that fires in open car parks buildings: i) have never led to any local collapse of the structure, and most of unprotected steel open sided steel-framed car parks has sufficient inherent resistance to withstand the fire effects; ii) are not frequent; iii) rarely involved more than three adjacent vehicles; iv) have never killed someone (only a few persons were 
recorded to be injured, and they were the owners of the cars). The main reasons that justify previous evidences are: in contrast to closed car parks, open car parks are characterized by high ventilation that keeps the fire limited on the ignition zone. Indeed, in an open car park building, the fire propagates from a burning car to another by radiation, convection and/or scattering of the fuel: by radiation, fire propagates sequentially from a car to another, but when the fifth or sixth car is burning, the combustion of the first one has already ended; the propagation of the fire by convection in an open car park building well ventilated is unlikely because hot gases have little impact on the cars; and the scattering of the fuel only happens in inclined floors [14].

The structural behavior of the car park under fire can be analyzed by specific combinations of mechanical and thermal loads defined in Eurocode 0 [15] and Eurocode 1, Parts 1.1 and 1.2 ([16], [17]). The methodology proposed in Annex C of Eurocode 1, Part 1.2 [17] for localized fires can be adapted to calculate the thermal loads of open car parks. In this case, fire scenarios are used to define the curve of the real rate of heat release of the burning vehicles, and thus to obtain an adequate fire characterization, against the traditional nominal fire curves defined by Eurocode 1, part 1.2 [17]. The vertical position of the virtual heat source, the height, the diameter of the fire, the rate of heat release and the distance between the fire source and the ceiling define the heat flux to the structural elements. Finally, simplified and advanced calculation methods are presented in Eurocodes 3 and 4, part 1.2 ([18], [19]) for calculating the resistance of structural elements in fire, depending on the fire safety requirements of each country. In France, CTICM validated this computing method to justify the use of unprotected steel frame resistance for the fire design, and the French legislation allowed this design methodology since 2004 (Decree of 22 March 2004).

The objectives of the presented study are: i) to present a fire engineering methodology, for assessing the structural behavior of steel and composite open car parks under fire, based on a Natural Fire Concept; ii) to compare the legislation of several European countries regarding the fire safety in this kind of building; and iii) to illustrate this design methodology through its application to an open composite car park with eight floors [3] and to compare the results with those obtained through advanced calculation methods.

\section{FIRE SCENARIOS}

The fire scenario (position of the vehicles) should represent the most unfavorable situation for the elements (or substructure). The vehicles' type mostly used in fire scenarios are cars, classified according their calorific potential or combustion energy (E) [1]; five classes of cars were defined: class $1-\mathrm{E}=6000 \mathrm{MJ}$ (ex. Peugeot 106); class $2-\mathrm{E}=7500 \mathrm{MJ}$ (ex. Peugeot 306); class $3-\mathrm{E}=$ $9500 \mathrm{MJ}$ (ex. Peugeot 406), and classes 4 and $5-\mathrm{E}=12000 \mathrm{MJ}$ (ex. Peugeot 605 or 806). According to statistical studies of actual fires in car parks, $90 \%$ of the vehicles involved in a fire are classified as class 1, 2 or 3 [1]. The INERIS - Institut National de l'Environnement Industriel et des Risques [14], considers that fire scenarios with cars of class 3 should be used to evaluate the structural stability of the car park under fire, and the fire resistance of the structure should be ensured during the entire fire scenario, or at least, if allowed by National requirements, up to a certain resistance time $\mathrm{R}$ of the elements defined as for the ISO curve. In addition, a scenario including a commercial vehicle (van containing $250 \mathrm{~kg}$ of highly flammable material: $\mathrm{E}=$ $19500 \mathrm{MJ}$ ) corresponds to an extreme situation and should only be used to check the global behavior of the structure, assuming local collapse, without progressive collapse [20].

Five fire scenarios recommended or already used for the study of fires in car parks are presented and described. ECCS [7] indicates that one or two vehicles in fire correspond to the most critical scenario in an open car park (Figure 1). One car burning at mid-span under the beam (corresponding 
to the maximum bending moment position) is defined as scenario 1 . The scenario 2 involves two burning cars, one on each side of the column; this fire event was considered being the most dangerous for the columns [7]. INERIS defines three additional fire scenarios [20]: i) scenario 1 of ECCS, but with a commercial vehicle under the beam, ii) scenario 3 - involving seven class 3-cars, with possibility of a commercial vehicle in places 0 or 1a (Figure 1), iii) scenario 4 - involving four class 3-cars parked face to face, with possibly a commercial vehicle in places $0,1 \mathrm{a}, 1 \mathrm{~b}$ or 2 . According to INERIS, and for all scenarios, the fire spread time from a vehicle to another is 12 minutes [20]; the initial document by ECCS [7] recommended a time delay equal to 15 minutes. The evolution of the composition of vehicles may also explain the decrease in the time delay (see Section 1). Another scenario already considered by CTICM [1] is scenario 5 (Figure 1): three class 3-cars, parked side by side. According to the same statistical source [1], a scenario of 3 class 3-cars (scenario 5) involved in a fire is an envelope scenario of around $98.7 \%$ of all possible scenarios.

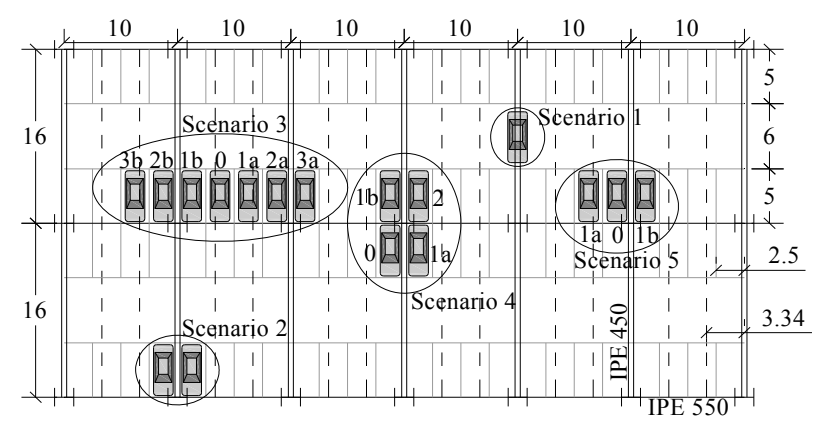

Figure 1. Fire Scenarios

(Represented in the Car Park Analyzed in this Paper; Dimensions given in m)

\section{RATE OF HEAT RELEASE FROM VEHICLES}

The model of a car under fire presented in the ECCS report [7] is based on experimental fire tests: it was observed that the flames extend out of the car, mainly through the windscreen and the rear window. The hot gases in the flames and above them move upward due to buoyancy; this flow of gases corresponds to the fire plume. The burning car is divided into two plumes which are called as the front and the rear fire plumes (Figure 2), and the sum of the heat releases included in the two fire plumes is equal to the heat release of the vehicle.



Figure 2. Front (F) and Rear (R) Fire Plumes [7]

In order to calculate the heat release, cars under fire have been experimentally studied in several countries [13]. Most of the tests were performed in closed conditions. The first tests carried out in opened conditions were developed by Mangs and Keski-Rahkonen in the 90's [21]. It was obtained that the total heat release of a European car from the 70's burning in an open car park building is equal to 4000 MJ. Between 1993 and 1996, the European project - Development of design rules for steel structures subjected to natural fires in closed car parks [22] - developed a design guide for closed car park structures subject to localised Natural Fires and established more realistic standards in Europe. Within this project, ten full-scale calorimetric fire experiments on old and recent European cars were performed by CTICM. In the first six tests, class 3-cars from the 70's and 80's 
were tested, while in the last four tests, newer cars (reference time: 1995) were used to simulate an open car park [14]. Based on these tests, reference curves of rate of heat release for two class 3-cars (one car as fire source and another one subject to the spread of fire with 12 minutes of delay) were defined [22]. These curves allow simulating multiple burning cars: Figure 3 presents the references curves for three consecutive burning class 3-cars, with maximum 8.3 MW. For commercial vehicles, CTICM suggests a maximum value of rate of heat release equal to $18 \mathrm{MW}$; this value is considered as a "safe value" for design, but this is not a measured value [20].

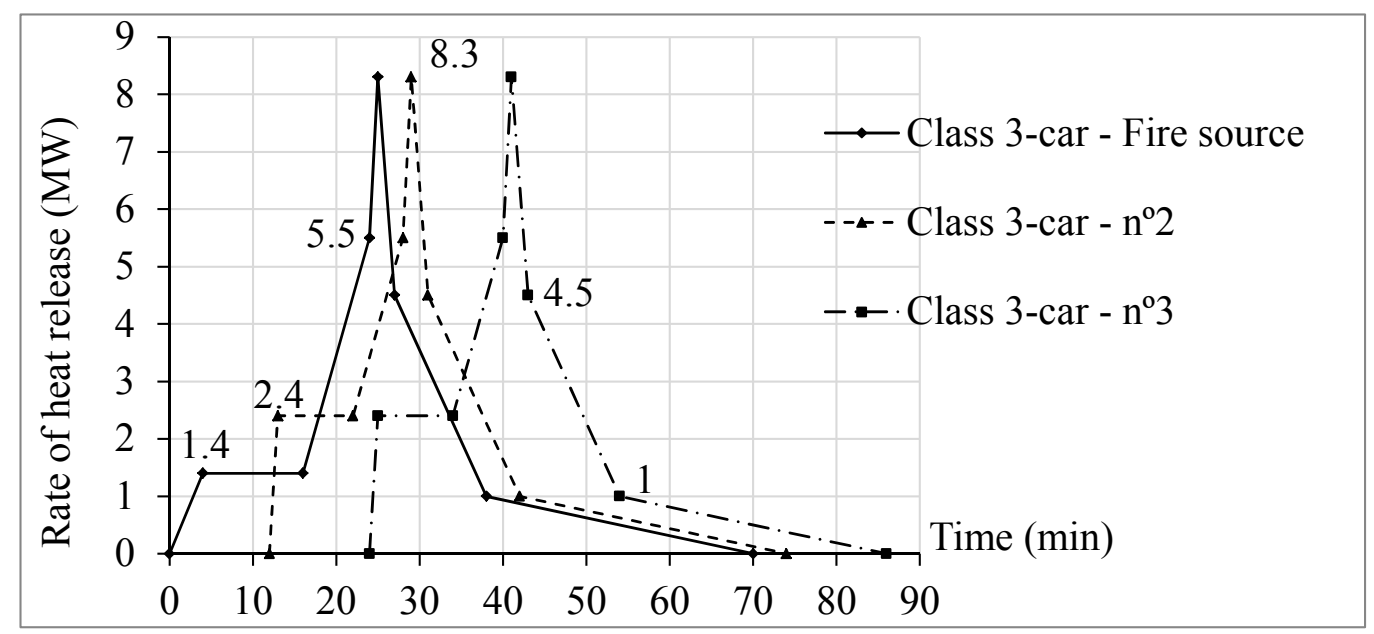

Figure 3. Curves of Rates of Heat Release from Burning of 3 Vehicles, Class 3

\section{STRUCTURAL BEHAVIOR}

\subsection{Combination of Actions}

The combination of actions for car parks under fire corresponds to the accidental design situations presented in Eurocode 0 [15]:

$$
\begin{aligned}
& \sum_{j \geq 1} G_{k, j}+P+A_{d}+\psi_{1,1} Q_{k, 1}+\sum_{i \geq 2} \psi_{2, i} Q_{\mathrm{k}, i} \\
& \sum_{j \geq 1} G_{k, j}+P+A_{d}+\sum_{i \geq 1} \psi_{2, i} Q_{k, i}
\end{aligned}
$$

where: $G_{k, j}$ are the characteristic values of permanent actions $j ; P$ is the design value of a prestressing load (if available); $A_{d}$ is the design value of indirect actions from fire; and $Q_{k, i}$ are characteristic values of the variable actions $i$. The difference between these two equations (1a) and (1b) is the coefficient applied to the leading variable action $\psi_{k, l}$ : the coefficients for the frequent value $\psi_{1}$ and for the quasi-permanent value $\psi_{2}$ are considered in expressions (1a) and (1b), respectively. In case of a car park (traffic with vehicles smaller than $30 \mathrm{kN}$ ), the coefficient for the frequent value $\psi_{1}$ and for the quasi-permanent value $\psi_{2}$ are respectively equal to 0.7 and 0.6 ; guidance may be given in the National Annex. The simplified combination of actions can be written as:

$$
\left.1.0 G_{k}+0.7 \text { (or } 0.6\right) Q_{k}
$$

Note that equation (1b) will lead to the situation where no horizontal action is considered in the fire situation because the quasi-permanent value of the wind $\psi_{2}$ is equal 0.0 [23]. 


\subsection{Mechanical loads}

The load model which should be used, given by the Eurocode 1 part 1.1 [16], is a load $q_{k}$ uniformly distributed on the floors for determination of general effects, and a single axis with a load $Q_{k}$ applied on two square surfaces for local effects (Figure 4), located in the position which will produce the most adverse effect of the action. Concerning characteristic values of the live loads, the Eurocode 1 part 1.1 [16] recommends that $q_{k}$ be selected within the range 1.5 to $2.5 \mathrm{kN} / \mathrm{m}^{2}$ and $Q_{k}$ be selected within the range 10 to $\underline{20} \mathrm{kN}$; the recommended values are underlined, but they may be set by the National Annex.

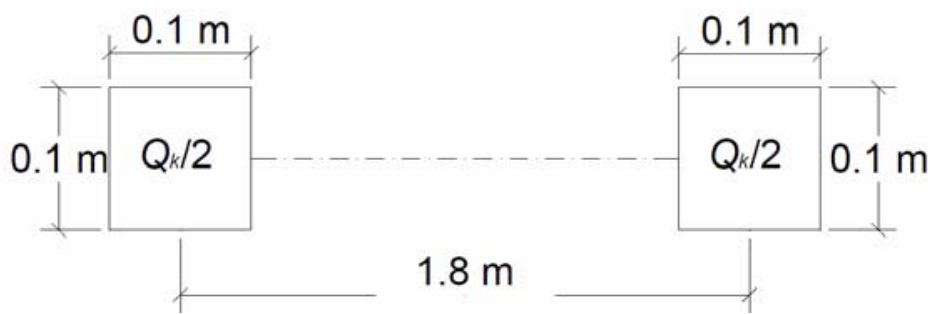

Figure 4. Dimensions of Axis Load

\subsection{Thermal loads}

The steel temperature of structural elements can be calculated in two ways: i) a simplified method that assumes a uniform temperature throughout the steel cross-section, and ii) an advanced method that considers the evaluation of the temperature field in the cross-section using finite element models. In this section, the simplified method given in the Eurocode 1 part 1.2 [17] is considered. The heat flux received by the members located at the ceiling level due to a localized fire is calculated by one of the simplified methods presented in Annex C of this code: i) Heskestad's method, when the flames are not impacting the ceiling, and ii) Hasemi's method, when the flames are impacting the ceiling. The length of the flame $L_{f}$ is obtained by:

$$
L_{f}=-1,02 D+0,0148 Q^{2 / 5} \quad[\mathrm{~m}]
$$

where $D[\mathrm{~m}]$ is the diameter of the fire (for a vehicle with an area equal to $12 \mathrm{~m}^{2}, D=3.9 \mathrm{~m} \mathrm{[22])}$ and $Q[\mathrm{~W}]$ is the rate of heat release of the fire, established in accordance with Annex E.4 of Eurocode 1, part 1.2 [17]. In this Annex, the heat release for car park occupancy is not specified; however, the experimental values presented in section 3 are considered in this study.

When the flames are not impacting the ceiling $\left(L_{f}<H\right)$, Eurocode 1 Part 1.2 [17] suggests that the temperature in the plume along the symmetrical vertical flame axis is given by:

$$
\theta_{(z)}=20+0,25 Q_{c}^{2 / 3}\left(z-z_{0}\right)^{-5 / 3} \leq 900\left[{ }^{\circ} \mathrm{C}\right]
$$

where the heat flux $Q_{c}[\mathrm{~W}]$ is the convective part of the rate of heat release $\left(Q_{c}=0.8 Q\right), z[\mathrm{~m}]$ is the height along the flame axis and $z_{0}[\mathrm{~m}]$ is the virtual origin of $z$ axis.

When the flame is impacting the ceiling $\left(L_{f} \geq H\right)$, the net heat flux $\dot{h_{n e t}}\left[\mathrm{~W} / \mathrm{m}^{2}\right]$ received by the fire exposed unit surface area at the level of the ceiling is given by:

$$
\dot{h_{n e t}}=\dot{h}-\alpha_{c}\left(\theta_{m}-20\right)-\Phi \varepsilon_{m} \varepsilon_{f} \sigma\left[\left(\theta_{m}+273\right)^{4}-(20+273)^{4}\right]\left[\mathrm{W} / \mathrm{m}^{2}\right]
$$


where $\dot{h}$ is the heat flux received by the unit of surface area exposed to fire at the ceiling level, $\alpha_{c}$ is the coefficient of heat transfer by convection $\left[\mathrm{W} / \mathrm{m}^{2} \mathrm{~K}\right], \theta_{m}$ is the surface temperature of the member $\left[{ }^{\circ} \mathrm{C}\right], \phi$ is the configuration factor, $\varepsilon_{m}$ is the surface emissivity of the member, $\varepsilon_{f}$ is the emissivity of the fire and $\sigma$ is the Stephan Boltzmann constant $\left(5.67 \times 10^{-8} \mathrm{~W} / \mathrm{m}^{2} \mathrm{~K}^{4}\right)$. Hasemi's method is a simple tool for the evaluation of the localized effect of a fire on horizontal elements located above the fire. The background of the method is experimental and based on tests made by Hasemi in Japan: a gas burner was placed under an unconfined flat ceiling, the height of the ceiling was adjusted in each test, and the heat flux to the ceiling surface was recorded [24]. This method cannot be used for the columns. The net heat flux from the fire of each vehicle to the horizontal structural members depends of the following parameters (Figure 5) [1]: $H_{s}[\mathrm{~m}]$ is the vertical distance between the fire source and the floor (equal to $0.3 \mathrm{~m} \mathrm{[7]);} H_{f}[\mathrm{~m}]$ is the vertical distance between the floor and the ceiling; $H[\mathrm{~m}]$ is the vertical distance between the fire source and the ceiling (or the lower flange of the beam); $r[\mathrm{~m}]$ is the horizontal distance between the vertical axis of the fire and the point along the ceiling where the thermal flux is calculated; $y$ is a parameter that depends on the diameter $D$, the rate of heat release $Q$ and on the distances $H$ and $r$. The net heat flux $(\dot{h})$ is calculated according the following expression [17]:

$\begin{array}{lll}\dot{h}=100000 & \text { if } y \leq 0.3 & \\ \dot{h}=136300-121000 y & \text { if } 0.3<y \leq 1 & {\left[\mathrm{~W} / \mathrm{m}^{2}\right]} \\ \dot{h}=15000 y^{-3,7} & \text { if } 1<y & \end{array}$



Figure 5. Parameters used in the Hasemi's Method to Calculate the Heat Flux from the Vehicle to the Beam

The net heat flux $(\dot{h})$ may be multiplied by a correction factor equal to 0.85 to account that the flame is deviated under the beam [24]. The heat flux from several localized fires is the sum of the heat fluxes obtained for each fire, with a maximum value of $100 \mathrm{~kW} / \mathrm{m}^{2}$ (see Equation 6); this limit was deduced from experimental tests made by Hasemi [25].

\subsection{Fire Design of Steel Members}

According to Eurocodes 3 and 4, part 1.2 ([18], [19]), there are three approaches to design structures exposed to fire: i) fire testing (very expensive and time consuming), ii) simplified methods, and iii) advanced methods. The simplified methods are based on conservative assumptions and only allow the use of nominal temperature-time curves for the design of individual members. The advanced calculation methods apply engineering principles in realistic and specific situations. In these methods, the fire can be modeled by means of Natural Fire curves (Fire Safety Engineering approach), and the indirect effects due to thermal expansions are considered; these advanced calculation methods can be applied to the fire analysis of any structural member. In the application example presented in section 6 , advanced calculation methods are used for structural analyses and safety checks, based on the use of natural localized fires. 


\subsection{Structural Fire Behavior of Steel Members}

The best characterization of the structural fire response of open car parks is the real evidence or experimental tests that reproduce closely the reality, such as the study performed in 2000 by CTICM [1]. The three fire tests were performed in a real unprotected composite steel-concrete car park; the first one included three class 3-cars (scenario 5 in Figure 1). The tested structure was defined by beams IPE 550 and columns HEB 200 and a steel-concrete composite slab connected to the beams by shear connectors; no fire protection was considered in the steel profiles. The fire test took 1 hour and $20 \mathrm{~min}$. and the maximum gas temperature near the ceiling reached $1040^{\circ} \mathrm{C}$ above the vehicle 0 ; however, the average gas temperature during the 15 minutes of higher temperatures was $510^{\circ} \mathrm{C}$, which means that a peak temperature was reached only during a very short time. The maximum temperature in the beam lower flange at a distance of $2.5 \mathrm{~m}$ from the column (half length of the vehicle) was $700^{\circ} \mathrm{C}$ with a gradient of $250^{\circ} \mathrm{C}$ in the cross-section. The column flange exposed to fire reached $640^{\circ} \mathrm{C}$ and $480^{\circ} \mathrm{C}$ respectively at $2 \mathrm{~m}$ and $1 \mathrm{~m}$ above the ground, with a gradient in the cross-section of $140^{\circ} \mathrm{C}$ and $150^{\circ} \mathrm{C}$ respectively. The maximum vertical displacement of the beam was $-70 \mathrm{~mm}$ (or $0.4 \%$ of the length); after cooling phase, a residual deformation of $+25 \mathrm{~mm}$ was observed. Just above the cars, lateral buckling and local buckling of the lower flange of the beam were observed. In the beam-column joint, 6 bolts (in a total of 8 ) broke, but no collapse of the structure was observed.

\section{FIRE REQUIREMENTS IN DIFFERENT EUROPEAN COUNTRIES}

The definition of open car park can differ from country to country, as shown in Table 2. This table also presents the limitations, the general requirements for fire ISO 834 and the indication of acceptance or not of alternative design conditions. It is shown that in some countries, this type of building does not require (or very few) any time of resistance under fire (ex.: R0 in Germany or R15 in U.K.). Portugal is one of the countries with the highest requirements for fire resistance of structural elements (from R60 to R180); however, the use of Natural Fire (defining scenarios and using the RHR curves) as an alternative to ISO 834 fire is accepted and it also allows limiting or avoiding any fire protection on steel elements. This table also shows that, actually, still $18 \%$ of European countries prescribe long fire time of resistance under the ISO 834 fire, and do not indicate anything about the use of Natural Fire (Hungary, Spain and Poland).

According to the ECCS report [7], steel structures in open car parks do not require fire protection, and therefore have economic advantages. The fire safety of these structures is ensured by the following conditions: i) the design at room temperature (or "cold design"), according to the current rules, is the basic condition for the stability of the structure in the fire situation; no additional measures for fire neither a special "hot" design are required; ii) beams with composite steel concrete section including shear studs should be used; for economic reasons, it is recommended to use light weight sections (IPE, HEAA and UB); iii) large flange sections (HEA, HEB, UC) should be considered for the columns; and iv) horizontal forces must be supported by frames or bracings (protected against fire). Additionally, CTICM [20] indicates: i) the same cross-sections for all columns in the same floor; these columns must be filled with concrete between the flanges, ii) use of concrete stairs to increase the horizontal stability and to be used as emergency stairs; iii) use a minimum steel grade of S355, and minimum concrete class of C30/37; iv) steel beams connected to the concrete slab by shear studs with a minimum degree of connection of $80 \%$; v) concrete slabs built in situ or precast concrete; the essential point is the static and structural integration of the slab in the load-bearing system [7]. 
Table 2. Resistance Requirements of Open Car Parks in Europe, According to the ECCS [7], and Updated in Accordance with the INERIS [14] and Other Documents

\begin{tabular}{|c|c|c|c|c|c|c|c|c|c|}
\hline \multirow[b]{3}{*}{ COUNTRY } & \multicolumn{6}{|c|}{ Limitations } & \multirow{3}{*}{$\begin{array}{c}\text { General } \\
\text { requirements } \\
\text { for fire ISO } \\
834\end{array}$} & \multirow{2}{*}{\multicolumn{2}{|c|}{$\begin{array}{l}\text { Alternative design } \\
\text { conditions }\end{array}$}} \\
\hline & \multicolumn{2}{|c|}{$\begin{array}{c}\text { Minimum } \\
\text { percentage of } \\
\text { openings (\%) }\end{array}$} & \multicolumn{4}{|c|}{ Maximum } & & & \\
\hline & $\begin{array}{l}\text { Openings } \\
\text { /floor }\end{array}$ & $\begin{array}{l}\text { Openings } \\
\text { /walls } \\
\text { and } \\
\text { façades } \\
(* 1) \\
\end{array}$ & $\begin{array}{c}\text { Dist. } \\
\text { between } \\
\text { opposite } \\
\text { façades } \\
\text { (m) } \\
\end{array}$ & $\begin{array}{c}\mathbf{n}^{\mathbf{0}} \text { of } \\
\text { stories }\end{array}$ & $\begin{array}{c}\text { Building } \\
\text { height } \\
\text { (m) }\end{array}$ & $\begin{array}{c}\text { Floor } \\
\text { area } \\
\text { per } \\
\text { story } \\
\left(\mathrm{m}^{2}\right) \\
\end{array}$ & & $\begin{array}{c}\text { No fire } \\
\text { protection }\end{array}$ & $\begin{array}{c}\text { Natural } \\
\text { fire } \\
(* 3)\end{array}$ \\
\hline Germany & - & 33 & 70 & - & 22 & - & R0 & / & / \\
\hline Austria & - & 33 & 70 & - & 22 & - & Up to $\mathrm{R} 90$ & Yes & Yes \\
\hline Belgium[26] & - & 17 & 60 & - & - & - & $\mathrm{R} 0$ to $\mathrm{R} 120$ & l & Yes \\
\hline Denmark & 5 & - & 24 & - & - & - & $\mathrm{R} 0$ to $\mathrm{R} 60$ & Yes & Yes \\
\hline Spain & - & - & - & - & - & - & $\begin{array}{l}\mathrm{R} 60 \text { to } \mathrm{R} 120 \\
\quad(* 2)\end{array}$ & - & - \\
\hline Finland & 10 & 30 & - & 8 & - & 9000 & $\mathrm{R} 60$ & No $(* 4)$ & Yes \\
\hline France[27] & 5 & 50 & 75 & - & - & - & Up toR90 & Yes & Yes \\
\hline Netherlands & - & 30 & 54 & - & 20 & - & $\mathrm{R} 0$ to $\mathrm{R} 30$ & l & l \\
\hline Hungary & - & - & - & - & - & - & $\begin{array}{l}\mathrm{R} 30 \text { to } \mathrm{R} 90 \\
(* 2)\end{array}$ & No & No \\
\hline Italy[28], [29] & 15 & 60 & - & - & - & - & $\mathrm{R} 0$ to $\mathrm{R} 90$ & - & Yes \\
\hline Luxemburg[30] & - & 50 & - & - & - & - & $\mathrm{R} 0$ to $\mathrm{R} 30$ & l & l \\
\hline Norway & - & 33 & - & - & 16 & 5400 & $\mathrm{R} 10$ to $\mathrm{R} 60$ & Yes & - \\
\hline Poland & - & - & - & - & 25 & 4000 & R60 & No & - \\
\hline $\begin{array}{l}\text { Portugal } \\
{[31] ;[32]}\end{array}$ & - & - & - & - & - & - & $\mathrm{R} 60$ to $\mathrm{R} 180$ & - & Yes \\
\hline U.K.[6] & 5 & - & - & - & 30 & - & $\mathrm{R} 15$ & Yes & Yes \\
\hline Sweden & - & - & - & - & - & - & $\begin{array}{l}\text { Up to R90 } \\
(* 2)\end{array}$ & Yes & Yes \\
\hline Switzerland & - & 25 & 70 & - & - & - & R0 & 1 & 1 \\
\hline
\end{tabular}

(*1): Total area of openings / total area of walls and façades surrounding one parking level.

$(* 2)$ : General requirements of National Building Code.

$(* 3)$ : Use of Natural Fire as an alternative to ISO fire to prove the fire resistance.

$(* 4)$ : Bare steel is allowed if this can be proved by tests or scientific studies.

As open car park buildings have general/typical dimensions with few variables, Corus in UK [6], ArcelorMittal in the center of Europe ([5], [30]) and One Steel in Australia [33] have already developed some typical sizing data sheets or examples in order to avoid the advanced sophisticated calculations.

\section{EXAMPLE OF APPLICATION}

The Fire Safety Engineering approach is based on the use of Natural Fires (as localized fires, defined by fire scenarios and their corresponding RHR curves) and then requires the use of advanced calculation methods for the structural analyses and safety checks. This design methodology based on fire scenarios is exemplified in this section by the application to an open composite steel-concrete car park with 8 floors, studied within the European RFCS Project ROBUSTFIRE [3]. The main and secondary beams are defined by IPE 550 and IPE 450, respectively (steel grade equal to $\mathrm{S} 355$ ). The height of each floor is $3 \mathrm{~m}$, and the cross-section of steel columns varies according to the floor (HEB 550 at the bottom two floors, HEB 400 and HEB 300 at the middle floors, and HEB 220 at the top two floors), the steel grade of the columns is S460. The lateral bracing of the structure is ensured by concrete ramps required for the car circulation. 
In this paper, four localized fires scenarios are studied in order to check the design of the secondary beam with two spans of $16 \mathrm{~m}$ each (IPE 450), the main beam with spans of $10 \mathrm{~m}$ (IPE 550) and the column of the fourth floor (HEB 300); cars of class 3 are used in the scenarios. The study of the global behavior of the structure, assuming local collapse without progressive collapse, has been disregarded, so commercial vehicle is not considered in the studied scenarios.

The fire scenario chosen for the secondary beams is scenario 1, with a vehicle under the mid-span of the beam (critical situation for the cross-section with hogging bending moment), whereas scenarios 4 and 5 correspond to the worst scenarios for the column study (Figure 1). Only class 3 -cars are considered. The design fire load is calculated according to Equation 7, considering the equation (1a) with $\psi_{l}=0.7$ :

$$
1.0 G_{k}+0.7 Q_{k}=1.0 \times 7.77 \mathrm{kN} / \mathrm{m}+0.7 \times 8.18 \mathrm{kN} / \mathrm{m}=13.50 \mathrm{kN} / \mathrm{m}
$$

For the main beam (IPE 550), scenario 3 is the worst fire scenario, and the design load is given by:

$$
1.0 G_{k}+0.7 Q_{k}=1.0 \times 25.91 \mathrm{kN} / \mathrm{m}+0.7 \times 26.16 \mathrm{kN} / \mathrm{m}=44.22 \mathrm{kN} / \mathrm{m}
$$

\subsection{Design According to the Simplified Methods}

In the simplified methods defined in Eurocodes 3 and 4, part 1.2 ([18], [19]), the fire design of a structural element can be performed in the temperature domain, time domain or resistance domain. These simplified methods cannot be used if Natural Fire (based on RHR fire curves) is taken into account, as explained in section 4.4. However, an attempt is made in this section to simplify the fire design of the beams under localized fire, using these simplified methods. In the temperature domain, it is considered that the element has a uniform temperature distribution and the failure is expected to occur when this temperature exceeds the critical temperature $\left(\theta_{\text {crit }}\right)$. In case of a localized fire, temperature is not uniform along the beam and using a critical temperature of the element is very conservative. In the resistance domain, the resistant bending moment of the structural element $M_{f i, \theta, R d}$ should be compared to the applied bending moment $M_{f i, E d}$ (assuming no lateral buckling because of the concrete slab). These two domains are checked for the study of the secondary beam.

Steel temperatures can be easily determined with program Elefir-EN [34], considering the following data: i) definition of the localized fire according to the number of vehicles included in the scenario, ii) curve of the rate of heat release of each car (Figure 2); iii) diameter of the fire, $D$ (for each car: $D=3.9 \mathrm{~m}$ ); iv) distance between the heat source and the ceiling $H=H_{f}-H_{s}-H_{\text {beam }}$ (Figure 5), with $H_{s}=0.3 \mathrm{~m}$; and v) horizontal distance between the vertical axis of the fire and the point along the ceiling where the thermal flux is calculated, $r(\mathrm{~m})$ (Figure 5). For each scenario, the flame length $L_{f}$ (see Equation 3) is greater than the height of the floor: the flame impacts the ceiling, so the Hasemi's method is considered.

The critical temperature $\left(\theta_{\text {crit }}\right)$ is also calculated with the program Elefir-EN [34], according to Eurocode 3, Part 1.2 [18]. The beam is exposed on 3 sides (the top flange supports a concrete slab), the adjustment factor $k_{1}$ (non-uniformity of temperature in the section) is equal to 0.7 and adjustment factor $k_{2}$ (non-uniformity of temperature along the beam) is considered equal to 1 . Figure 6a shows the results of the critical fire scenario 1; the critical temperature is equal to $653^{\circ} \mathrm{C}$ and a maximum temperature $\left(\theta_{\max }\right)$ of $706^{\circ} \mathrm{C}$ is reached in the beam after $28 \mathrm{~min}$. In this case, it is necessary to protect the beam using $3 \mathrm{~mm}$ of cement with vermiculite, for example. If resistance domain is considered, the maximum sagging bending moment is equal to $244.5 \mathrm{kNm}$ (mid-span). At $28 \mathrm{~min}$. of fire (uniform steel temperature of $706^{\circ} \mathrm{C}$ ), the resistant bending moment of the 
composite beam section is equal to $255 \mathrm{kNm}$, which is higher than the applied bending moment; no fire protection is needed. The concrete slab is assumed to be at ambient temperature; this assumption is based on the results from the CTICM tests [1]: maximum temperature equal to $250^{\circ} \mathrm{C}$ was measured at the bottom of the slab and in an area restricted to the area of fire. Scenario 3 with seven cars (Figure 1) is the critical fire scenario for the main beam (IPE 550). Figure 6b shows the temperature curves: the critical temperature of $724^{\circ} \mathrm{C}$ is reached after $32 \mathrm{~min}$. and a maximum temperature of $543^{\circ} \mathrm{C}$ was calculated in the beam; no fire protection is needed, even in the more conservative temperature domain. However, if Portugal regulation is considered, the structure resistance should be R90 [31] (this building has more than $9 \mathrm{~m}$ in height, and it is $2^{\text {nd }}$ category of risk [32]); moreover, if curve ISO 834 is used to check this structure for the resistance R90, $11 \mathrm{~mm}$ and $25 \mathrm{~mm}$ of cement with vermiculite are needed to protect main and secondary beams, respectively. Table 3 summarizes and compares these results.

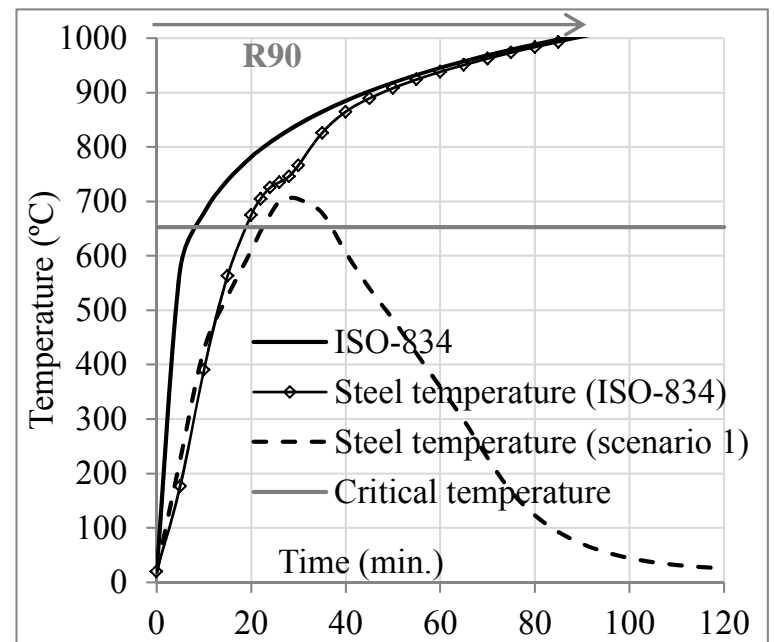

a) Beam IPE 450 (scenario 1)

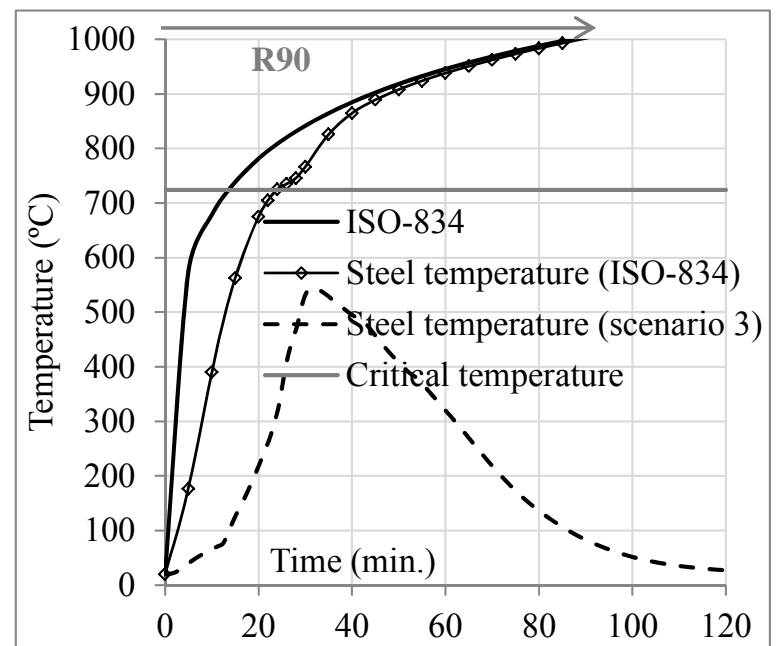

b) Beam IPE 550 (scenario 3)

Figure 6. Comparison between the Steel Temperature in Beams IPE450 and IPE550 subject to ISO 834 Fire and to the Most Unfavorable Fire Scenarios for Each Beam

\subsection{Design According to the Advanced Calculation Methods}

The design of the same structure through an advanced calculation method is now presented and the results are compared with those obtained in section 6.1. Since with the method based on fire scenarios and applied in a simplified way, no fire protection is needed to the main beam, advanced calculation method will only be applied to composite secondary beam (scenario 1). Additionally, the advanced calculation methods will also be used to evaluate the fire resistance of the column (scenarios 4 and 5). The finite element program Abaqus [35] is used to perform the thermal and structural analyses.

\subsubsection{Thermal analysis}

The thermal loads for the beams are defined taking into account the following procedure: i) the gas temperatures that surround the beam are calculated using the program Elefir-EN: as the flame impact the ceiling, the Hasemi's method is considered and the gas temperature corresponds to the flame temperature $(H=2.25 \mathrm{~m})$; ii) a heat transfer analysis is performed in Abaqus for each composite section located along the beam (emissivity factor equal 0.7 and convection coefficient equal to $35 \mathrm{~W} / \mathrm{m}^{2} \mathrm{~K}$ ); the model of the composite beam is developed using $2 \mathrm{D}$ deformable element DC2D4. Figure 7 depicts the temperatures evolution in the steel beam section for each scenario; the presented curves correspond to the cross-sections with maximum temperatures: mid-span of the beam for scenario 1 and at $2.5 \mathrm{~m}$ from the column for scenarios 4 and 5 . 
a)

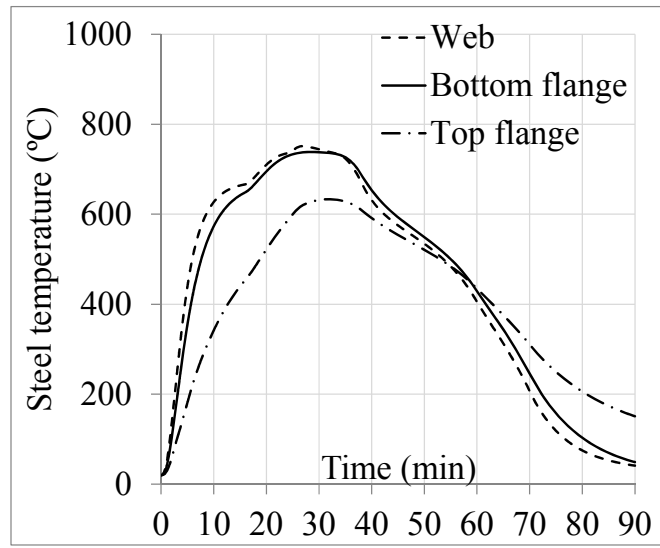

b)
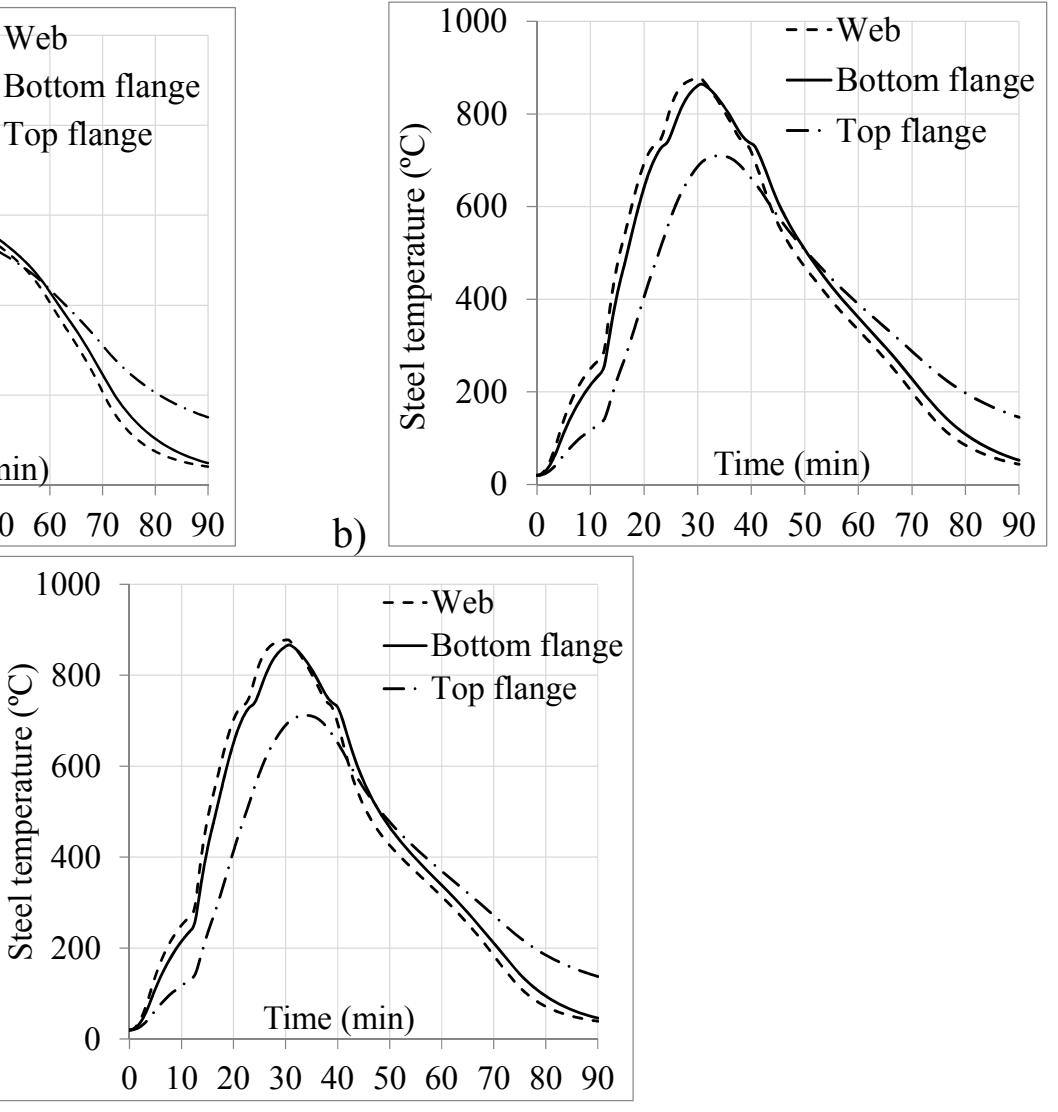

Figure 7. Temperature Evolution in the Secondary Beam IPE 450 under: a) Scenario 1 (Mid-span), b) Scenario 4 (at $2 \mathrm{~m}$ from the Column) and c) Scenario 5 (at $2 \mathrm{~m}$ from the Column)

Figure 8 presents the variation of the average temperature in each section of the secondary beam during the fire for each scenario, while Figure 9 presents the variation of the average temperatures in each section of the secondary beam versus the position at $30 \mathrm{~min}$. of fire. In these charts are represented the weighted average temperatures of the steel beam section.

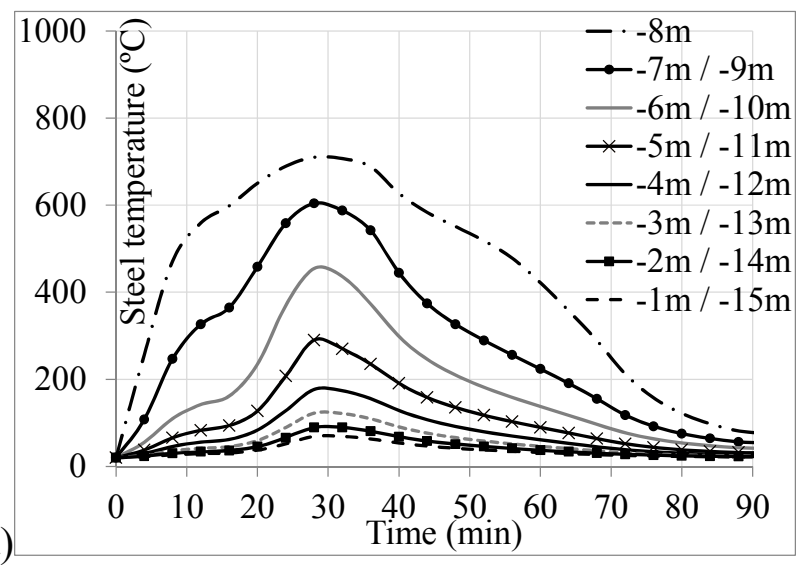

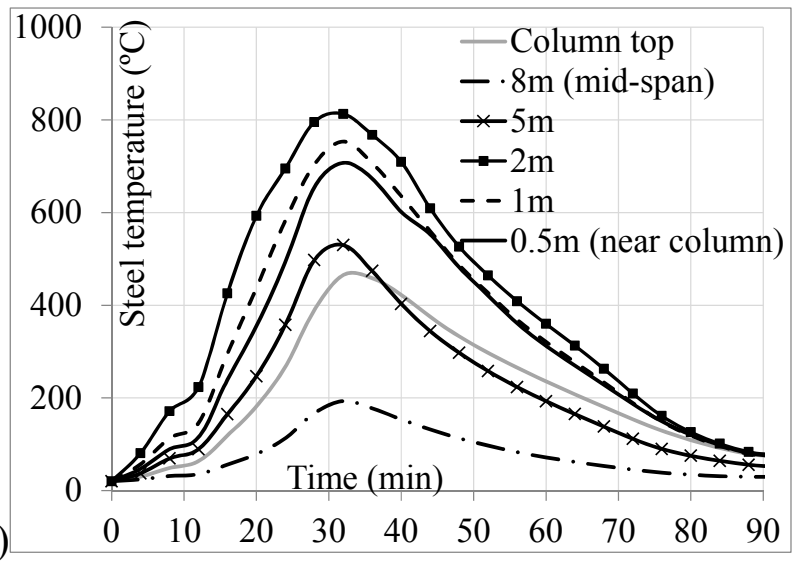






Figure 8. Variation of the Weighted Average Temperatures in Section of the Secondary Beams IPE 450 versus time: a) Scenario 1, b) Scenario 4 and c) Scenario 5

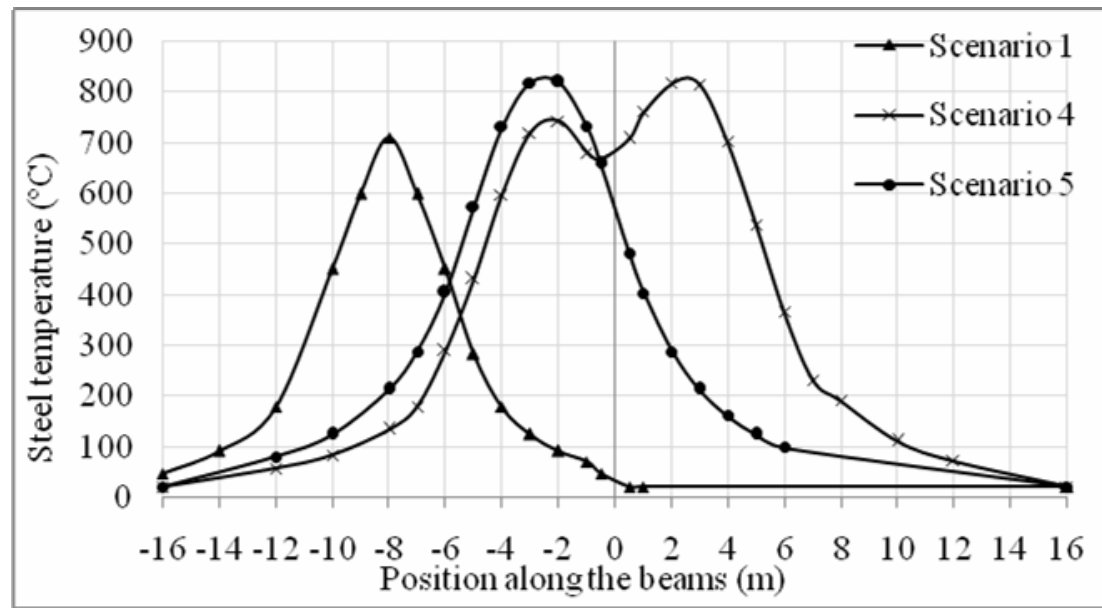

Figure 9. Variations of the Weighted Average Temperatures in Section of the Secondary Beam IPE 450 after 30 min. of Fire Versus Position along the Beams (scenarios 1, 4 and 5)

\subsubsection{Mechanical analysis}

In this example, the two dimensional frame includes the secondary beams of $16 \mathrm{~m}$ length each (Figure 10) and the columns (weak axis). The composite beams are modeled with an equivalent rectangular section (identical section and inertia than the real composite beam; additionally inertia considering cracked concrete is considered near the supports). The beams affected by the fire scenarios developed at the fourth floor are modeled by beam elements for the steel profile, and shell elements for the slab (the composite slab is simplified to a reinforced concrete slab of thickness equal to $120 \mathrm{~mm}$ ). The width of the slab is $3.4 \mathrm{~m}$, which corresponds to the effective width of the mid-span. The initial deformation of $h / 1000(3 \mathrm{~mm})$ is applied to the columns. Beams elements are used for the beams and the columns not directly affected by the fire. Mechanical loads correspond to the values presented at the beginning of section 6 . Only third, fourth and fifth floors are modeled, taking into account loads from the upper floors. 


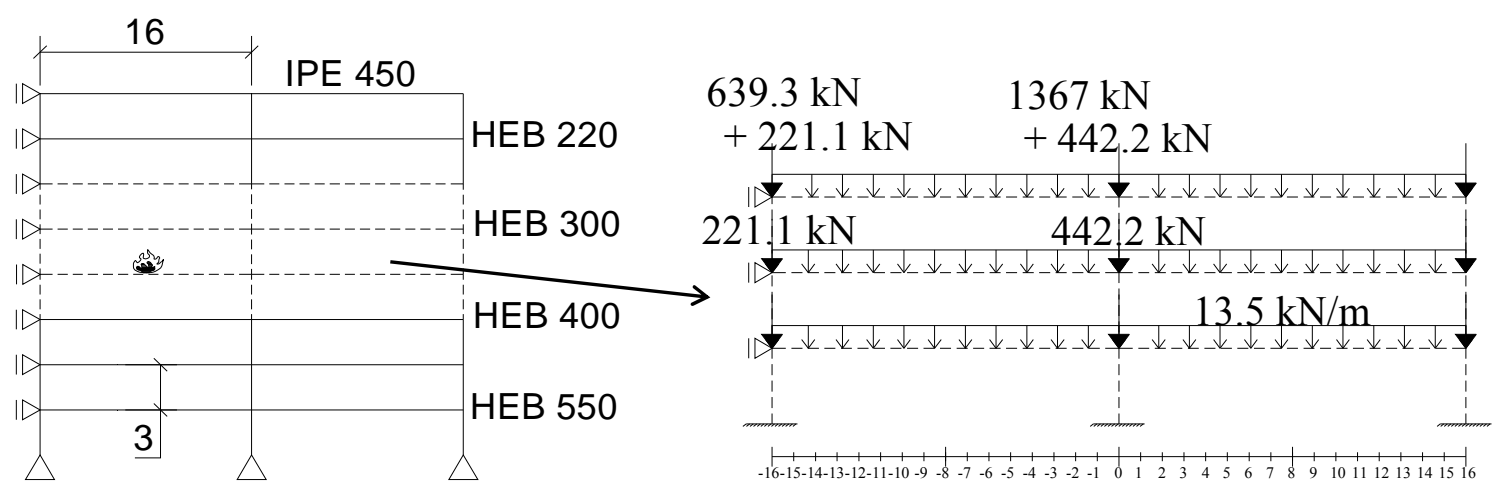

Figure 10. Studied Car Park Versus Numerical 2D Frame (Loaded)

The calculated temperatures gradients are directly applied to the steel beam sections in the static analysis, using the option "predefined fields". The concrete slab is assumed to be at ambient temperature throughout the analysis, as justified previously. The scenario 4 corresponds to the worst fire scenario for the column, with four class 3-cars burning around it. Because no accurate (and simple) method is defined to calculate the column temperature in case of a localized fire, the temperature at the column top is assumed to be the same than an HEB 300 beam (calculated by Hasemi's method). This temperature is applied uniformly along the column height (except below the heat source, at $0.3 \mathrm{~m}$ above the floor, where $20^{\circ} \mathrm{C}$ are considered). The concrete properties are set in accordance with Eurocode 2 Part 1.2 [36], and steel properties vary with temperature as defined in Eurocode 3 Part 1.2 [18].

Figure 11 shows the development of the vertical displacement at the beam mid-span for each fire scenario. For the scenario 1, a maximum displacement equal to $122 \mathrm{~mm}$ downwards (which includes the initial displacement of $21 \mathrm{~mm}$ due to the mechanical loading) is reached after $15 \mathrm{~min}$. of fire. After the fire, the beam shows a residual camber, with a displacement at mid-span equal to $102 \mathrm{~mm}$ upwards. Because i) of the high thermal gradients in the cross-section of the composite beam (unheated concrete slab), and ii) the axial restraint to thermal expansion due to the lateral bracing and the unaffected part of the building, high compression loads developed at the beam bottom flange, which inverted the bending moment from sagging to hogging moment. This thermal bowing developed at the beam mid-span after $17 \mathrm{~min}$. of fire. If thermal deformations or expansions were not restrained, the axial compression loads would not have increased and thermal bowing would not have happened. This highlights the importance of using advanced calculation methods within Fire Safety Engineering, where indirect actions due to restrained thermal deformations or expansions are considered.

Under scenario 4, the column is not able to resist to the entire fire and fails by yielding of the cross-section after 28 min. of fire (three plastic hinges are developed at the top, bottom and at the mid-height of the column - Figure 11). However, according to the statistics, this scenario never happened in reality in an open car park building, and the application of uniform temperatures along the column height is a very conservative hypothesis [22]. An additional verification of the column, based on the realistic fire scenario 5 including three burning cars, is performed. For this scenario, the column temperatures measured during the first French test [1] are assumed: average values of $405^{\circ} \mathrm{C}$ and $570^{\circ} \mathrm{C}$ were measured at $1 \mathrm{~m}$ height and at $2 \mathrm{~m}$ height, respectively. The column and the beams resist to this fire scenario, with maximum $196 \mathrm{~mm}$ of beam vertical displacement at $32 \mathrm{~min}$ (Figure 11). 


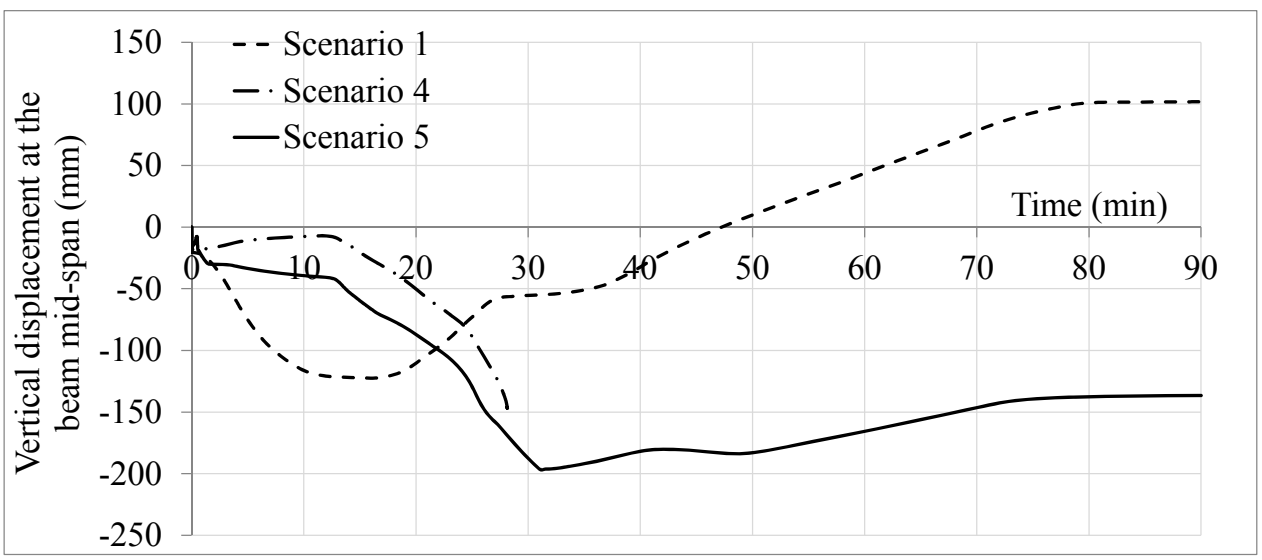

Figure 11. Evolution of the Beam IPE 450 Mid-span Vertical Displacement During Fire

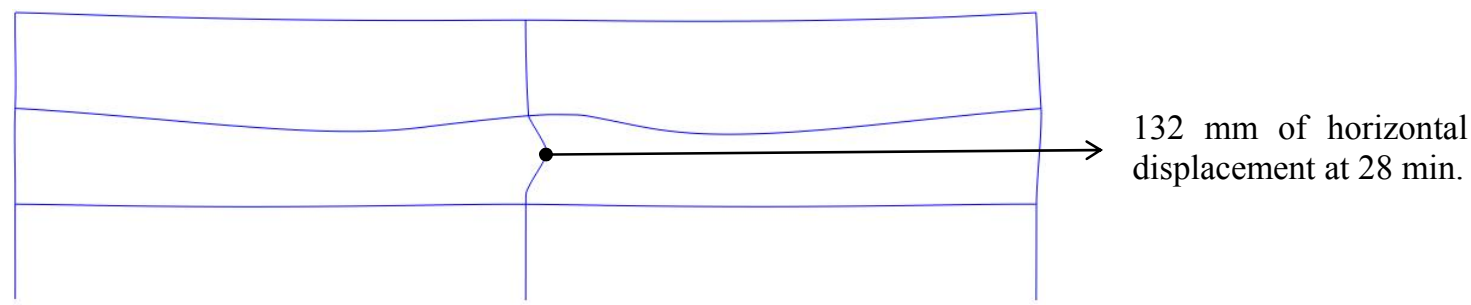

Figure 12. Frame Deformation at 28 min of Fire (Scenario 4): Column Failure (Scale 5)

Standard ISO 834-1 [37] relating to fire resistance tests indicates that failure of an element subject to bending under fire should be considered when the maximum vertical displacement $\sigma_{\text {max }}$ exceeds the values indicated by Equation 9:

$$
\delta_{\max } \leq \frac{L^{2}}{400 d}=1123 \mathrm{~mm}
$$

Where $L[\mathrm{~mm}]$ is the span of the beam and $d[\mathrm{~mm}]$ is the distance from the extreme fiber of the design compression zone to the extreme fiber of the design tensile zone of the structural section. The maximum displacements of the studied beam are lower than these values, and it can be considered that the beam does not fail under any of these fire scenarios. For the column, the same standard restricts the maximum axial contraction $\sigma_{\text {vert,max }}$ of axially loaded elements to Equation 10 :

$$
\delta_{\text {vert, } \max } \leq \frac{h}{100}=30 \mathrm{~mm}
$$

Where $h[\mathrm{~mm}]$ is the initial height. The studied column reached this limit after $28 \mathrm{~min}$. of fire in scenario 4, but reached smaller contraction (max. $24 \mathrm{~mm}$ ) in scenario 5. French prescriptions [20] usually prescribe to add concrete between the column flanges in order to protect the column (see section 5), which is a solution that could be done if scenario 4 needs to be checked.

\subsection{Summary of the Results}

Table 3 summarizes the results obtained for the beams and the column, according to the simplified and advanced methods. 
Table 3. Summary of the Design Results for Beams IPE 450 and IPE 550

\begin{tabular}{|c|c|c|c|c|c|c|}
\hline & & nplified meth & & \multirow{2}{*}{\multicolumn{3}{|c|}{ Advanced methods }} \\
\hline & \multicolumn{3}{|c|}{ Temperature / resistance domain } & & & \\
\hline & Scenario 1 & Scenario 3 & ISO 834 & Scenario 1 & Scenario 4 & Scenario 5 \\
\hline $\begin{array}{c}\text { IPE } 550 \\
\left(\theta_{\text {crit. }}=724^{\circ} \mathrm{C}\right)\end{array}$ & --- & $\begin{array}{c}\theta_{\max }= \\
543^{\circ} \mathrm{C} \\
(32 \min .)\end{array}$ & $\begin{array}{l}\theta_{90 \min .}= \\
1001^{\circ} \mathrm{C}\end{array}$ & --- & --- & --- \\
\hline $\begin{array}{l}\text { Prot. * ex.: cement } \\
\text { with vermiculite }\end{array}$ & --- & No need & $\begin{array}{l}11 \mathrm{~mm} \\
\text { thick }\end{array}$ & --- & --- & --- \\
\hline $\begin{array}{c}\operatorname{IPE} 450 \\
\left(\theta_{\text {crit. }}=653^{\circ} \mathrm{C} / M_{f i, E d}\right. \\
=244.5)\end{array}$ & $\begin{array}{c}\theta_{\max }= \\
706^{\circ} \mathrm{C} \\
(28 \mathrm{~min} .) \\
=255 \\
\mathrm{kNm}\end{array}$ & --- & $\begin{array}{l}\theta_{90 \min .}= \\
1001^{\circ} \mathrm{C}\end{array}$ & $\begin{array}{c}\sigma_{\max }=122 \\
\mathrm{~mm} \\
(15 \mathrm{~min} .)\end{array}$ & --- & $\begin{array}{c}\sigma_{\max }=196 \\
\mathrm{~mm} \\
(32 \mathrm{~min} .)\end{array}$ \\
\hline $\begin{array}{l}\text { Prot. }{ }^{*}: \text { ex.: cement } \\
\text { with vermiculite }\end{array}$ & $\begin{array}{c}3 \mathrm{~mm} \\
\text { thick / No } \\
\text { need }\end{array}$ & --- & $\begin{array}{l}25 \mathrm{~mm} \\
\text { thick }\end{array}$ & No need & --- & No need \\
\hline Column HEB 300 & --- & --- & --- & --- & $\begin{array}{c}\sigma_{\text {vert }}>30 \\
\mathrm{~mm}\end{array}$ & $\begin{array}{c}\sigma_{\text {vert.max }}=24 \\
\mathrm{~mm}\end{array}$ \\
\hline $\begin{array}{c}\text { Prot. }{ }^{*} \text { ex.: concrete } \\
\text { between flanges }\end{array}$ & --- & --- & --- & --- & Need! & No need \\
\hline
\end{tabular}

*Prot. $=$ fire protection

\section{CONCLUDING REMARKS}

The fire design of steel and composite structures from open car park can be made in accordance with Eurocodes: Eurocode 1 Part 1.1 [16] defines the mechanical loads, while Annex C and Annex $\mathrm{D}$ of Part 1.2 [17] present a simplified method for determining the flame temperature around the beams. The calculation of these temperatures depends on the total rate of heat release, which is determined based on the fire scenarios. The reference curve for the rate of heat release was defined based on results of experimental tests performed on actual vehicles. Finally, Eurocodes 3 and 4, Part 1.2 ([18], [19]) present the calculation models for these structures.

From previous experimental tests in real open car park buildings, it was concluded that most of unprotected steel open sided steel-framed car parks has sufficient inherent resistance to withstand the effects of any fires that are likely to occur. These results have encouraged to change the legislations in several European countries, allowing to build steel or composite steel-concrete open car parks without fire protection, taking into account a design based on the actual performance of the structure and not on prescribed nominal design curves (that in most of the cases, require fire protection with considerable thickness).

The simplified design methods defined in Eurocodes 3 and 4, part 1.2 ([18], [19]), are based on conservative assumptions and only allow the use of nominal temperature-time curves for the design of individual members. When the structure is subject to Natural Fire defined by RHR fire curves, the choice must involve the use of advanced calculation methods rather than simplified methods in order to consider the indirect effects due to restrained thermal expansions.

Design of columns under localized fires can only be done, for now, using advanced models; no accurate and simple method is available to calculate the column temperature due to a localized fire. Hasemi's method is a simple tool for the evaluation of the localized effect of a fire on horizontal elements located above the fire, but cannot be used for the columns. Finally, the example clearly 
showed the advantage of using the design methodology based on fire scenarios against the use of ISO curve; it was verified that the unprotected composite steel-concrete structure resists to the studied fire scenarios.

In conclusion, the design methodology based on fire scenarios allowed optimizing the structure to benefit from an appropriate level of fire safety, reducing the fire protection and therefore the final cost of this type of building.

\section{ACKNOWLEDGEMENTS}

The research leading to these results has received funding from the European Community's Research Fund for Coal and Steel (RFCS) under grant agreement $n^{\circ}$ RFSR-CT-2008-00036 project ROBUSTFIRE: "Robustness of Car Parks against Localized Fire".

\section{REFERENCES}

[1] Joyeux, D., Kruppa, J., Cajot, L.-G., Schleich, J.-B., Van de Leur, P. and Twilt, L. "Demonstration of Real Fire Tests in Car Parks and High Buildings", European Commission, Contract No. 7215-PP/025 (1993 - 1996), CTICM, Final Report, EUR 20466 EN, 2002, pp. 168.

[2] Simões da Silva, L., Santiago, A. and Haremza, C., "ROBUSTFIRE Project, Document 1 Car Parks - V1(11)", Internal Document, University of Coimbra, 2009, pp. 71.

[3] Demonceau, J.F., Huvelle, C., Comeliau, L., Hoang, L.V., Jaspart, J.P. and Fang C., et al. "Robustness of Car Parks Against Localised Fire", European Commission, Grant Agreement Number RFSR-CT-2008-00036, Final Report, 2012.

[4] Cajot, L.-G., Mathieu, J. and Thomas, L., "Les Structures Métalliques Pour Les Parking Souverts", La revue de Métallurgie-CIT, November 2003, pp. 8.

[5] Arcelor Mittal, "Parkings Aériensmét Alliques Large Mentventilés", Les carnets de l'acier, 2007, No 9, pp. 34.

[6] Corus, "Steel-framed Car Parks", Corus Construction \& Industrial, 2004.

[7] ECCS, "Fire Safety in Open Car Parks", Modern Fire Engineering, Technical Committee 3, $\mathrm{n}^{\circ} 75$, European Convention for Constructional Steelwork: Brussels, Belgium, 1993, pp. 90.

[8] Butcher, E.G., Langdon-Thomas G.H., Bedford G.K. "Fire Car Park Buildings", Fire Note 10, HMSO, U.K, July 1968.

[9] Gewain, R.G. "Fire Experience and Fire Tests in Automobile Parking Structures." Fire Journal, 1973, Vol. 67, No. 4, pp. 50-54.

[10] Bennetts, I.D., Proe, D.J., Lewins, R.R. and Thomas I.R. "Fire and Unprotected Steel in Closed Car Parks". BHP Melbourne, Research Laboratories Report Number MRL/PS98/87/001, August 1987.

[11] Zhao, B. and Kruppa, J. "Structural Behaviour of An Open Car Park under Real Fire Scenarios", Second International Workshop "Structures in Fire" - Christchurch - March 2002, Fire and Materials, 2004, Vol. 28, pp. 269-280.

[12] Li, Y. and Spearpoint, M., "Analysis of Vehicle Fire Statistics in New Zealand Parking Buildings", Fire Technology, 2007, Vol. 43, pp. 93-106.

[13] Li, Y. "Assessement of Vehicle Fires in New Zealand Parking Buildings". Fire Engineering Research Report 04/2, Master Thesis, University of Canterbury, New Zealand, May 2004.

[14] Cwiklinski, C., "Parcs de Stationnement en Superstructure Large Mentventilés - Avis d'expertsur les scénariosd 'incendie", Rapport final, INERIS DRA-CCw/ MCh-2001-cgr22984, 2001, pp. 26. 
[15] EN 1990:2002, "Eurocode - Basis of Structural Design", European Committee for Standardization, April 2002, pp. 87.

[16] EN 1991-1-1:2002, "Eurocode 1: Actions on Structures - Part 1-1: General Actions Densities, Self-weight, Imposed Loads for Buildings", European committee for standardization, April 2002, pp. 44.

[17] EN 1991-1-2:2002, "Eurocode 1: Actions on Structures - Part 1-2: General Actions Actions on Structures Exposed to Fire", European Committee for Standardization, November 2002 , pp. 59.

[18] EN 1993-1-2:2005, "Eurocode 3: Design of Steel Structures - Part 1-2: General Rules Structural Fire Design”, European Committee for Standardization, April 2005, pp. 78.

[19] EN 1994-1-2:2005, "Eurocode 4: Design of Composite Steel and Concrete Structures - Part 1-2: General Rules - Structural Fire Design", European Committee for Standardization, August 2005, pp. 109.

[20] Fraud, C., Zhao, B., Joyeux, D., Kruppa, J., "Guide Pour la Vérification du Comportement au Feu de Parcs de Stationnement Large Mentventilés en Superstructure Métallique”, CTICM, INSI - 03/233d - BZ/PB, 2004, pp. 75.

[21] Mangs, J. and Keski-Rahkonen, O., "Characterisation of the Fire Behaviour of a Burning Passenger Car. Part I: Car Fire Experiments." Fire Safety Journal, 1994, Vol. 23, pp. 17-35.

[22] Schleich, J.-B., Cajot, L.-G., Pierre, M., Brasseur, M., Franssen, J.-M. and Kruppa, J. et al., "Development of Design Rules for Steel Structures Subjected to Natural Fires in Closed Car Parks", European Commission, C.E.C. Research 7210-SA/518. Final Report EUR 18867 EN, 1999 , pp. 154.

[23] Franssen, J.-M. and Vila Real, P. "Fire Design of Steel Structures", ECCS Eurocode Design Manuals, Ernst \&Sohn, $1{ }^{\text {st }}$ Edition, 2010.

[24] Schleich, J.B., Cajot, L.G., Pierre, M., Brasseur, M., Franssen, J.M., Kruppa, J., Joyeux, D., Twilt, L., Van Oerle, J. and Aurtenetxe, G. "Development of Design Rules for Steel Structures Subjected to Natural Fires in Large Compartments", European Commission, Contract No. 7210-SA/211/318/518/620/933, 1999.

[25] EC1-1-2/71, "Background Document on Localized Fires According to Annex C of prEN1991-1-2 (24-08-2001)", Profil ARBED, Centre de Recherches, CEN/TC250/SC1/ N339, 2001.

[26] Arrêté royal fixant les mesures en matière de préventioncontrel'incendie et l'explosionauxquelles les parkingsfermésdoiventsatisfaire pour le stationnement des véhicules LPG, MoniteurBelge, BelgischStaatsblad. Ed. 3, 20 of June, 2007, pp. 33997.

[27] Arrêté du 9 mai 2006 portant approbation de dispositions complétant et modifiant le règlement de sécuritécontre les risquesd'incendie et de paniquedans les établissementsrecevant du public (parcs de stationnementcouverts), Ministère de l'intérieur et de l'aménagement du territoire, Journal Officiel de la RépubliqueFrançaise, 8 juillet 2006.

[28] Ministry of Interior (Italian Government), Decree 9 May 2007. Direttive per l'attuazionedell'approccioingegneristicoallasicurezzaantincendio, GU n. 117 del 22 maggio 2007.

[29] Nigro, E., Cefarelli, G., Ferraro, A., Manfredi, G. and Cosenza, E., "Fire Safety Engineering for Open and Closed Car Parks: C.A.S.E Project for L'Aquila", Applied Mechanics and Materials, Vol. 82, pp. 746-751, 2011. ISSN: 1662-7482. doi:10.4028/www.scientific.net/ AMM.82.746.

[30] ArcelorMittal - "Car parks in steel”, Comercial Sections, 1996, 30p.

[31] Portaria nº1532/2008”, Diário da República, $1^{a}$ série, N. ${ }^{\circ}$ 250, 29 de Dezembro, 2008, pp. 9050-9127.

[32] Decreto-Lei nº220/2008, Diário da República, $1^{\text {a }}$ série, N. ${ }^{\circ}$ 220, 2008, pp. 7903-7922.

[33] Economical Carparks - A Design Guide, Australia, $2^{\text {nd }}$ Edition, 2004. 
[34] Vila Real, P. and Franssen, J.M. - Elefir-EN V1.2.3, Software for Fire Design of Steel Structural Members According the Eurocode 3, 2010. http://elefiren.web.ua.pt.

[35] ABAQUS - Theory Manual \& Users Manuals, v. 6.11, Hibbitt, Karlsson and Sorensen Inc., 2011.

[36] EN 1992-1-2:2004 - "Eurocode 2: Design of Concrete Structures - Part 1-2: General Rules Structural Fire Design”, European Committee for Standardization, December 2004, pp. 97.

[37] ISO 834-1, "Fire-resistance Tests - Elements of Building Construction - Part 1: General Requirements", International Standard, $1^{\text {st }}$ Edition, 1999. 